\title{
The Use of Explicit Instruction in Writing Amongst Students of Colleges of Education in the Ashanti Region of Ghana
}

\author{
Yaa Asantewaa Bediako
}

St. Monica's College of Education, Ghana

Doi:10.19044/esj.2021.v17n38p75

Submitted: 26 October 2021

Accepted: 10 November 2021

Published: 30 November 2021
Copyright 2021 Author(s)

Under Creative Commons BY-NC-ND

4.0 OPEN ACCESS

Cite As:

Bediako Y.A. (2021). The Use of Explicit Instruction in Writing Amongst Students of Colleges of Education in the Ashanti Region of Ghana. European Scientific Journal, ESJ, 17 (38), 75. https://doi.org/10.19044/esj.2021.v17n38p75

\section{Abstract}

The study sought to examine the use of Explicit Instruction in writing lessons at some selected Colleges of Education in the Ashanti Region of Ghana. The collective case study design informed by constructivist grounded theory data analysis methods was used. Data were collected and analyzed using three instruments namely a semi-structured interview, sample texts on argumentative and expository essays and observations. The study revealed that combining the cognitive strategy of text structure knowledge application with the metacognitive strategy of self-monitoring supports the development of academic writing in students in the Colleges of Education. Also, students make mistakes in their writing and these mistakes include verb errors, article errors and wrong words. It was also revealed that with regards to Explicit Instruction in the classroom, tutors comprehensively used instructions in the language class to enhance students writing skills. This study further showed that tutors have a variety of evidence-based instructional practices that improve many different skills and student's writing knowledge. The researcher recommended that students in Colleges of Education in Ghana are made to read extensively outside the curriculum to broaden their vocabulary repertoire so that the over-reliance on tutors for corrections can be minimized.

Keywords: Explicit Instruction, Tutors, Expository essays, Writing Skills 


\section{Introduction}

One of the aims of education is to ensure that students are able to read and write expository text (Bruning \& Horn, 2000). For students to be successful in school, at work, and in the society depends greatly upon the ability to comprehend this type of text. Every country, the world over has its native tongue as its first language and the acquisition of another language as a second or official language. In Ghana, for instance, English is taught in Ghanaian schools both as a Second Language (ESL) and as a Foreign Language (EFL). The different skills of English language are taught as part of the English studies curriculum. In the aspect of writing as part of English Language studies, two things happen in the classroom: the mechanics of writing and composition. When second language (L2) students are learning how to write English, they begin with letters of the alphabet, words and short sentences and experience problems with linguistic accuracy (Silva, 1993; Hinkel, 2002, 2004; Hartshorn, Evans, Merrill, Sudweeks, Strong-Krause, \& Anderson, 2010). Then, when they develop in their writing, thus producing larger and more complex pieces of text, they may experience problems at the paragraph and essay level, for example, in developing their ideas (Zhu, 2001; Bitchener \& Basturkmen, 2006; Leki, et al. 2008). Therefore, L2 writing, regardless of what stage a student is can be a challenge.

At the basic level of education in Ghana, the same teacher usually handles all the aspects of language in the classroom; thus, the onus lies on such a teacher to be skillful in all the aspects of the language. Students who do not sufficiently master basic writing skills may have difficulty participating in activities that involve communicating in school (Koster, Tribushinina, de Jong, \& van den Bergh, 2015). Furthermore, many individuals show limited or no improvement in their writing skills once they have learned how to structure a simple sentence (Salahu-Din, Persky, \& Miller, 2008). A number of meta-analyses on writing instruction, but with different foci, have demonstrated the benefits of supporting the development of writing skills. Some have focused on the effect of strategy instruction interventions on students' writing performance. In a world where writing as a skill is used as a performance tool, it would be unfortunate if a teacher after going through training or even in training cannot perform to show that acquisition of the writing skill has been done successfully. Attempts then have to be made to ensure that this skill is developed properly while in training before they are sent out to teach. Clark (2013, p.9) asserts that, "good writing doesn't happen by accident...successful writers use mental procedures to control the production of writing. We call these mental procedures writing strategies.

Writing strategies are deliberate focused ways of thinking about writing". In an academic setting like a College of Education in Ghana where students who have graduated from Senior Secondary School cannot write 
properly, it behooves on teacher trainers to find appropriate strategies and activities that could be used to develop the writing skills of such students as writing is a tool that can be used for different purposes. Evidence from end of semester examination scripts show students' poor performances in writing as an aspect of English language. Students need to be consciously aware of their shortcomings and effective teaching requires that these areas of error must be systematically taught through corrective feedback in the course of instruction (Olagbaju, 2019).

Effective explicit writing instruction should be expected in every classroom. Students in Colleges of Education having gone through Basic education up to the Senior High School are expected to have acquired an appreciable level of communication skills. It is somewhat alarming that some students of Colleges of Education in the Ashanti Region cannot organize their ideas and thoughts comprehensibly to communicate (English class observation, 2019). Writing should be a routine just like other things in life. Although some may think of the daily routines of life as being boring and mundane, student writers and teachers alike find our writing routines comforting and confidence building (Greiner \& Simmons, 2012). If the main aim of the student-teacher is to teach students in the near future, what they need to know and what they need to be able to do is to know how to write.

Explicit Instruction, according to Archer \& Hughes (2011, p.1) "is a structured, systematic, and effective methodology for teaching academic skills. It is an unambiguous and direct approach to teaching that includes both instructional design and delivery procedures". Archer \& Hughes, (2011, p.1) described this form of instruction as "a systematic method of teaching with emphasis on proceeding in small steps, checking for student understanding, and achieving active and successful participation by all students". With College of Education students who are going out to teach, it becomes a very essential tool without which the success of their professional training will be questioned.

The lack of writing skills and competencies prevent them from answering questions from the writing sections of their examinations correctly. A good number of students, for instance, in a language lesson classroom at St. Monica's College of Education have problems with spelling and choice of appropriate register to meet the demands of the topics the writing activities are based on. Research has indicated minimal expository text instruction occurs during the elementary years (Pressley, Rankin, \& Yokoi, 1995; Duke, 2000). Duke (2000), in a study in Minnesota, in the United States of America found that first-grade students spent only 3.6 minutes each day learning from expository text. Pressley et al. (1995) found that elementary school teachers in Minnesota reported using expository text in only 6\% of their reading instruction. 
There are multiple students today with negative mindsets with regards to writing. Some have had bad experiences when writing papers, some never received writing instruction, and some are not confident in their writing abilities. Again, there is ample research to suggest that many children are not learning to read and write expository text competently (Duke, 2000). The use of Explicit Instruction to develop writing among students of Colleges of Education in the Ashanti Region of Ghana will bring to the fore the challenges that the students face as writers as well as identifying a way of addressing the situation. As an educator, it can be frightening how much effect we can have on the mindsets of our students, but it can also be empowering. It is easy to focus on students who struggle with their writing perceptions. Based on the available literature on the use of Explicit Instruction in writing, there is a gap when it comes to students' ability to write and also have good registers. In the field of argumentative and expository essay writing, no research has been conducted to know the impact of Explicit Instruction in student-teacher writings in the Colleges of Education in Ghana. The purpose of this paper is to present the findings of Explicit Instruction in writing lessons in St. Monica's College of Education.

\section{Research Questions}

The research questions of this study are:

1. How is Explicit Instruction used in developing writing among language students of Colleges of Education in the Ashanti Region of Ghana?

2. What activities and strategies should tutors employ to help students of Colleges of Education in the Ashanti Region of Ghana acquire writing skills and find success in their writing exercises?

\section{Review of Related Literature}

\section{Using Explicit Instruction to Develop Students Writing}

Many students struggle with little success on writing tasks because writing is a complex task. Students with learning disabilities (LD) generally perform at lower rates on writing tasks than their English-only speaking peers without disabilities (Viel Ruma, 2008). In addition to being a necessary skill for school success, writing is a complicated task that requires students to be cognizant of the mechanics of language (e.g., grammar, spelling, capitalization), while simultaneously expressing meaningful content through the use of appropriate vocabulary selection and a format appropriate for each particular type of writing genre (De La Paz \& Owen, 2000). Challenges in writing are magnified for students with learning disabilities (LD) in the area of written expression. This group of students often lacks the cognitive abilities to meet all of the complex cognitive processes required to complete many 
writing tasks (Bui, 2002). Such cognitive deficits can negatively impact those students ${ }^{\text {ee }}$ abilities to employ grammatically correct usage in the course of planning and developing written text. In general, students with LD produce writing samples of a poorer quality than the samples of their peers without disabilities (Newcomer \& Berenbaum, 1991). Students with LD also tend to place an overemphasis on transcription skills (Graham, Harris, \& Larsen, 2001). Transcription skills are those that relate to handwriting, spelling, and punctuation (Brooks, Vaughan, \& Berninger, 1999). Because of the heightened emphasis on form, students with LD tend to pay more attention to the lower-level mechanical skills instead of composing meaningful text (Palinscar \& Klenk, 1992). Students with LD also spend minimal time planning to write (Graham \& Harris, 2000). This is critical because the amount of time spent planning has been shown to be key to the quality of the final written product (Bereiter \& Scardamalia, 1987). Therefore, the finished written products of students with LD are generally less coherent and meaningful than those of their peers without disabilities (Wong, Butler, \& Ficzere, 1997).

A wealth of research has underscored the importance of Explicit Instruction as an effective methodology in teaching language skills (Bomer, 1991; Price, 1998; Serafini, 2004; Geoke, 2008; Archer \& Hughes, 2011; Amer, 2013). Explicit Instruction often refers to the systematic sequencing of instructional procedures in a lesson. Dockrell, Marshall and Wyse (2016, p.410) say "the complexity of the writing process places significant demands on teachers' expertise and teaching time". There are a range of key skills that need to be taught and arranged in different ways in which teaching can occur. To help teachers' structure what is taught and how it should be taught, a framework outlining the writing process could inform practice. A developmental model of the writing processes provides an understanding of writing development and has the potential to identify developmental differences and points for instruction.

Setyowati \& EL-Sulukiyyah (2019) also posit that having good writing ability is crucial in this modern world. It is crucial, because it is only from the act of writing, that one's intellectuality and quality can be seen and acknowledged, moreover, writing helps people to acquire self-consciousness, knowledge, creativity and crucial thinking ability. They also say that, to be able to write well is a long and tiring process. It is not enough for the students to have topics and ideas to write only. The students need to tailor those ideas through the use of proper language to make the sentences understandable and arrange those ideas logically so that they are meaningful for the readers. For students in college, for one to be able to do writing successfully, there is a need to identify a strategy that could be used effectively to develop the writing skills of these students for them to become competent writers. Such writers will 
write with their audience in mind and also consider the Genre on which they are writing to be able to employ whatever cognitive abilities they need to write effectively.

\section{Effects of Explicit Instruction on Writing}

The different skills of English language are taught as part of the English studies curriculum in Ghanaian schools. Students' success and chances of progression on the academic ladder is largely dependent on their achievement in public and private English language examinations. Olagbaju (2015) opines that summary skill has become a veritable communication skill because it is a part of our daily life as one cannot give a verbatim report of everything that one has seen, read, experienced or heard. Therefore, human beings are constantly and unconsciously conducting summaries daily without the slightest knowledge of it.

Learning can occur in diverse ways. Therefore, there are different cognitive style dimensions which include field divergent/convergent, field dependent/independent, holistic/sequential, reflective/impulsive, global/analytic cognitive styles. Explicit instruction allows for partnership between teachers and students during instructional procedure. The teacher is expected to model the steps and present the objectives of the lesson, demonstrate clarity and enthusiasm while the students participate actively through guided practice sessions, independent practice session and corrective feedbacks. Hughes, Morris, Therrien \& Benson (2017) opined that components used in an intervention often vary across research studies (e g; one study might use four Explicit Instruction components while another uses six) makes a precise answer difficult. It is also difficult to parse out which components are directly related to the outcome; the impact of a particular component may vary due to the nature of what content is being taught, to whom it is being taught, and whether a component is being underused, overused and misused.

Crown (2009) published the outcome of a study using Explicit Instructional Strategies to teach narrative writing and found that students were able to transfer the skills they had gained in narrative writing to writing in another genre - in this case, poetry. Also, Adebiyi (2012) examined the effects of Explicit and Generative Instructional Strategies on students' achievement in reading comprehension and found that Explicit Instructional Strategy has a significant effect on students' achievement in reading comprehension. Similarly, Duke (2001) conducted a study to investigate the effect of building comprehension through explicit teaching of comprehension strategies on students' performance and found that Explicit Instructional Strategy has a significant effect on students' comprehension. Hall (2002) found that students who received Explicit Instruction in reading, mathematics, language, and 
spelling achieved better in these basic skills, as well as reading comprehension, problem solving, and mathematics concepts. Also, students' scores in the group exposed to Explicit Instruction were reported to be above the other treatment groups. Also, Akinoso (2012) investigated the effects of Explicit Instructional Strategy on Mathematics and reported that the strategy had a significant effect on students' achievement in and attitude to the subject. Although the findings of the studies above have produced useful insights into the effects of Explicit Instructional Strategy on students' achievement in the different subject areas, there are still some obvious limitations.

Feng \& Powers (2005, p.42) are of the opinion that outstanding writing teachers do not only recognize the importance of a "little love and understanding", they also stress the importance of tailoring instructions to meet the individual needs of students experiencing difficulty in learning how to write. Hughes et al (2017, p.145) citing Joseph, Alber-Morgan \& Neef (2016) contend that many teaching behaviors included in explicit instruction (e.g. modelling, prompting, frequent opportunities to respond, accompanied with feedback are aligned with applied behavior analysis principles such as positive reinforcement (feedback), carefully arranging examples, consistent use of terms (stimulus control), and modeling (orienting attention to critical stimuli), still others like Berliner, 1980; Brophy \& Evertson (1976) describe how Explicit Instruction and Direct Instruction components (e.g., clear presentations, dynamic models, frequent responding, guided practice with feedback) address basic prerequisites of learning such as academic learning time (Gettinger \& Seibert, 2002) cited in Hughes, et. Al., (2017) an opportunity to respond. It is instructive to note that while theories and perspectives on why Explicit Instruction is effective vary, the instructional behaviours and components do not to a great degree. When learners are not good writers as Tsegaye (2006) says, they use run-on, incorrect and fragmented sentences. Students of Colleges of Education in the Ashanti Region may not have the necessary English language skills to cope with writing assignments. They may have difficulty understanding or keeping up with the readings on which written assignments are based. They may also simply have trouble with grammar, syntax, spelling, and vocabulary. Even students who possess the necessary language skills may be unfamiliar with the kinds of writing assignments they are asked to do in college classes. It was in a right direction when Alfaki (2015) stated that a good writing on composition should consist of appropriate and varied range of vocabularies used.

\section{Using Explicit Instruction to Develop Students Writing of Argumentative and Expository Essays}

Writing is perceived as a recursive process because the writer needs to spend time revisiting and reflecting on his/her work (Tarnopolsky, 2000). A 
process-based approach constitutes a paradigm shift that views writing as a procedure of developing organization, involving strategies, multiple drafts, and formative feedback. Oshima \& Hogue (2006) state that an essay is a piece of writing several long paragraphs. It is about one topic, just as a paragraph is. Because the topic of an essay is too complex to discuss in one paragraph, you need to divide it into several paragraphs, one for each major point. Then you need to tie the paragraphs together by adding an introduction and a conclusion. Because an essay is long, it is important to organize and plan before you begin to write. The best way to do this is to make an outline. An outline not only organizes your thoughts, but it also keeps you on track once you begin to write. It is important to recognize that in order to write an essay well, you must commit yourself to a process (Starkey, 2004). Writing in particular for academic purposes is necessarily prepared since there are many aspects to be concerned for a good writing. Langan (2008) explained that an essay is a relatively short piece of non-fiction in which a writer attempts to develop one or more closely related points or ideas. Essays are shorter pieces of writing that often require the student to have a number of skills such as close reading, analysis, comparison and contrast, persuasion, conciseness, clarity, and exposition. As is evidenced by this list of attributes, there is much to be gained by the student who strives to succeed at essay writing.

For effective writing, the writer has to use a large number of formal features in order to help his/her readers infer the intended meaning. Failure to use these features correctly causes vagueness, ellipsis and ambiguity in writings. Writing in EFL classes is difficult for both teachers and students because there are many aspects to deal with. Raimes (1983, P.6) mentions those aspects are syntax, content, the writer's process, audience, purpose, word choice, organization, mechanics and grammar. Byrne (1993, P.3) mentions three aspects which make writing difficult. The first is the psychological problem. Writing is a solitary activity that teachers cannot get direct feedback like in speaking activity. The second is linguistics problem. The writers have to ensure that the choice of words, sentence structure, and other cohesive devices are correct for conveying their message. The last is the cognitive problem. Writing is learned through the process of instruction. It is not a natural process like speaking. Both Raimes \& Byrne basically have the same idea, but Raimes does not classify the problem. Audience and purpose of writing is included in Byrne's psychological problem. Bryne's linguistic problem covered syntax, word choice, mechanics and grammar. Many students still make errors and mistakes and, then, they are fossilized. Their interest becomes less and less and students begin to create negative stimuli about learning to write. This condition drives the students to assume that writing is a very difficult task to do. The problem emerges as students are not familiar with the type of written discourse in English due to lack of exposure. 
Many teachers perceive arguments as akin to conflict and avoid teaching it. The concept of audience is often dealt with inadequately, resulting in student writing for their primary audience, the teacher. Furthermore, teachers cannot always articulate rules to evidence, causality and proof, evidence or warrant for claims, assumptions that can be taken for granted, and premises that can be defended' (Newell et al. 2011) and thus provide appropriate support for students. According to Amer (2013) Expository writing differs from narrative and descriptive writing in that it expresses an idea about a topic and uses supporting details to inform or explain to the reader that the idea is sound. While the narrative or descriptive modes attempt to evoke the reader's emotions or senses, the exposition mode resides in the realm of logic.

\section{Metacognition in Teaching and Learning}

Educational psychologists such as Dewey used the terms "active monitoring," "critical evaluation," and "seeking after meanings and relationships" to depict reflective reading activities now subsumed under the rubric "metacognition" (Brown, 1987). Garofalo and Lester (1985) see metacognition as originally stemming from an article criticizing the lack of research on memory which particularly noted no one was considering the fact that people have knowledge and beliefs about their memory processes. Flavell (1979) began to study children's "metamemory" and went on to become a pioneer in the field of metacognition. Metacognitive Strategies are employed for managing the overall learning process (e.g., identifying one's own learning style preferences and needs, planning for an L2 task, gathering and organizing materials, arranging a study space and a schedule, monitoring mistakes, evaluating task success and the success of any type of learning strategy). According to Flavell (1979) metacognition, commonly understood as "thinking about thinking", refers to the knowledge and control people have over their thinking process and is described as a crucial part of SRL. Flavell (1979) hypothesized that metacognitive experiences were more likely to happen in situations that require high cognitive attention, for example, while working on a job or school task, or any other activity that requires careful planning, monitoring, and evaluation. To illustrate a metacognitive experience, imagine that you are listening to your instructor teaching, and suddenly you realize that you do not understand a certain concept. This realization makes you write a note in the margin of your textbook to go back and review after class. Flavell also recognized that metacognitive experience and metacognitive knowledge overlap at times. To improve critical thinking, noted researchers (Fink, 2013; Halpern, 1998; Hattie, Gurung \& Landrum, 2015; Schraw, Crippen, \& Hartley, 2006) have suggested focusing on developing students' metacognitive skills and abilities. Schraw, Crippen \& Hartley (2006) provide a useful framework for understanding the relationships 
between SRL, critical thinking, and metacognition. Significant research has shown that students who apply metacognitive strategies in their learning tend to be better critical thinkers and, therefore, perform better academically (Bransford, Brown, \& Cocking, 2000; Dewyer, Hogan, \& Stewart, 2014). Metacognition involves both awareness and control of one's cognitive processes. The National Research Council (2001) described metacognition as "the process of reflecting on and directing one's own thinking" (p. 78). Classroom research shows that students who apply metacognitive strategies are more likely to excel in problem-based learning (Rozencwajg, 2003; Hmelo-Silver, 2004), self-regulation (Butler \& Winne, 1995; Pintrich, 2004; Schunk \& Zimmerman, 2003; Narciss, Proske, \& Koerndle, 2007), selfefficacy and motivation (Wolters \& Pintrich, 1998; Dinsmore et al., 2008; Ormrod, 2011; Zull, 2011), expert learning (Bransford, Brown, \& Cocking, 2000; Sternberg, 1998, 2003), and in academic achievement (Hartman, 2001; Justice \& Dornan, 2001). Integrating metacognition into course content is widely supported as one of the most effective methods when teaching, learning, and utilizing metacognition, and certain metacognitive strategies have been found to be especially effective (Fink, 2013).

\section{Method \\ Participants}

The study's subjects were second-year students in the language department of St. Monica's College of Education, Atebubu College of Education and Wesley College of Education. From 426 candidates, a total of 150 students were selected using the lottery sampling technique while the purposive technique was used to select 4 tutors from four schools. The students were exposed to a total of two expository and argumentative essays. They were given instructions on what to do with regard to the number of words to write which was 350 words as they do in their end of semester exams and the duration was 40 minutes. The sample essays were used in order to ascertain if students could write essays based on the requirements of each genre type. Thus, the author tried to ascertain if students followed instructions given in class discussions.

\section{Instruments}

Using a qualitative approach, data were collected and triangulated using interviews, Observations and sample essays. Semi-structured interviews were conducted with 4 of the teachers. Semi-structured interviews created the opportunity for "specific issues to be addressed" (Briggs, 2007). They also enabled the interviewees and the interviewer to be more engaged in the communication process if certain aspects needed to be addressed in greater detail than anticipated by the planned interview questions (Briggs, 2007). An 
interview topic guide was used to structure the interviews. However, additional questions were also asked by the researcher during the interview to explore teachers' experiences more in-depth when considered necessary. The interviews lasted between a minimum of 50 minutes to an hour. Despite the issues faced by the researcher, she believed the interview data to be valid because when the interviews were disrupted, she ended them as soon as possible to avoid any bias occurring. The researcher visited each of the tutors interviewed earlier during teaching to seek first-hand information on what actually went on during writing lessons in the classroom. Each session lasted an hour and aside recording observations, photographs and both video and audio recordings of the lessons were taken. These were all studied to ascertain how good the information collected was for the study. The use of recording and the observation record book was to have a backup or support should one fail. During the sessions, the researcher was alert and very attentive to what was going on because she was a non-participant in the study. She sat by and watched how the class was led by the teachers to the end of the scheduled time. The focus was on how and what instructions were used during writing lessons. Students were thus made to write the two essays two weeks apart. The first was the expository and the next was the argumentative. The students were spoken to, to avoid any cheating as marks were not going to be awarded. They had been given prior notice of the writing activity but did not know what genre or question they were to write on. In all three classrooms were used and each class had fifty students.

\section{Data Collection and Analysis}

Participation in the study was voluntary, information about the aim of the study was shared, and informed consent was obtained before data collection. The researcher collected data from participants via interviews, expository and argumentative writings. With the interviews, the researcher decided to use open coding, inspired by a grounded theory approach, for the analysis stages. The researcher believed that it was easier to analyze data by grouping them into categories or subcategories before combining them into themes, rather than developing themes and then fitting all the data into the themes. Open coding was used at the beginning to open up the data to every potential and all possibilities contained within them. After considering meanings related to the data and examining the context, interpretive conceptual labels were then put on the data (Corbin \& Strauss, 2008). Crosscase analysis was done to look for patterns and themes that cut across individual experiences (Patton, 2002). According to Glaser and Strauss (1967) cited in Patton (2002) "this helps ensure that emergent categories and discovered patterns are grounded in specific cases and their contexts". The researcher extracted themes and sub-themes for all the sites separately. The 
purpose of doing that was to understand the relationship between individual cases and sites and to look for any similarities, nuances or differences in themes or sub-themes between sites. Some themes that emerged were influenced by the researcher's initial thematic structure.

\section{Findings and Discussion}

The study's findings are structured around the research questions. The first question solicited how effective Explicit Instruction is used in developing writing among language students of Colleges of Education in the Ashanti Region of Ghana? The responses showed whether students followed instructions given in class discussions. The essay was analyzed under the following criteria as indicated under the genre theory: background, proposition, refutation, support, conclusion, paragraph development, punctuation, spelling and language expression. The essays were scored excellent, very good, good, poor, very poor and absent according to how well students presented these features in their essays. To examine students' ability in writing the essay, the researcher considered the Genre and students' knowledge on it. This was because the Genre Theory uses materials and tasks based on authentic linguistic data in order to create students' awareness of the conventions and procedures of the genre in question.

Table 1: Analysis in writing essays (argumentative/expository)

\begin{tabular}{llllllll}
\hline & Excellent & $\begin{array}{l}\text { Very } \\
\text { good }\end{array}$ & Good & Poor & $\begin{array}{l}\text { Very } \\
\text { poor }\end{array}$ & Absent & Total \\
\hline Background & 0 & 3 & 27 & 32 & 18 & 70 & 150 \\
Proposition & 0 & 3 & 72 & 68 & 5 & 2 & 150 \\
Qualification & 0 & 0 & 0 & 0 & 0 & 150 & 150 \\
Refutation & 0 & 3 & 27 & 18 & 0 & 102 & 150 \\
Support & 0 & 4 & 135 & 11 & 0 & 0 & 150 \\
Conclusion & 0 & 6 & 14 & 105 & 14 & 11 & 150 \\
Paragraph Dev't & 0 & 6 & 107 & 16 & 37 & 0 & 150 \\
Punctuation & 0 & 0 & 79 & 36 & 28 & 0 & 150 \\
$\begin{array}{l}\text { Spelling } \\
\text { Language }\end{array}$ & 0 & 3 & 100 & 36 & 11 & 0 & 150 \\
expression & 0 & 6 & 70 & 64 & 8 & 0 & 150 \\
\hline
\end{tabular}

Of the 150 essays considered, 3(2\%) students scored very good, $27(18 \%)$ had good and $32(21.3 \%)$ also scored poor marks in the background column of the essay. Again, $25(16.7 \%)$ did not write any background information by way of introducing their essay. These students started writing their essay by discussing whatever ideas they had with regards to the question. On language and expression, 70 (46.7\%) performance were good. However, none of the students was excellent in their write-ups. Every argument is composed of obligatory elements such as claim and data and secondary elements, such as counterargument, and rebuttal. The results of the study 
showed that not every student had a conclusion in her work. Of the number, six (6) students wrote very good conclusions, fourteen (14) of them had good marks and one hundred and five (105) of them had poor conclusions. This number of students ended the essay by concluding with a summary of the major points discussed, eight (8) of them were graded very poor and eleven (11) of them did not write any conclusion. These students ended their essays without any conclusion. Of the entire texts from the students, only $25 \%$ ended their essays with a conclusion. This finding is consistent with the findings of other researchers who conducted studies in the use of Explicit Instruction.

Analysis from the data shows a gross composition deficiency among most of the students. From data collected on the sample essay texts on expository writing, it was realized that if students are furnished with strategies for text organization that are appropriate for writing expository essays and they are made aware of general organizational structures such as thesis statement, body, conclusion, logical relationships among parts of a text, and options available at hand for selecting and arranging their information in a text, they would be able to write effectively.

Table 2: Analysis of students' expository essay

\begin{tabular}{lllll}
\hline Activity & Good & Poor & Very Poor & Total \\
\hline Purpose of writing & 67 & 67 & 16 & 150 \\
Textual structure & 73 & 41 & 36 & 150 \\
Rhetorical structures & 75 & 39 & 36 & 150 \\
Topic expression & 75 & 45 & 30 & 150 \\
Voice & 74 & 33 & 43 & 150 \\
Discourse markers & 82 & 30 & 38 & 150 \\
Relation between writer and reader & 75 & 16 & 59 & 150 \\
\hline
\end{tabular}

Students were expected to write their essays starting with a good introduction or a statement on the purpose of the writing. Students were to examine the effects of technology in Education. 67(44.7\%) of the students were able to write a good introduction or state a purpose of the writing with $16(10.7 \%)$ performed poorly. The language generally was not good and this was seen in the spelling, tenses and sentence writing.

The pre-intervention test conducted using the traditional product approach presented a lot of errors and mistakes in students' essays. Among the very basic errors detected in students' essays were:

i. Wrongful use of some punctuation marks

ii. Lack of knowledge of capitalization as in starting a new sentence with the lower-case letters

iii. Writing too lengthy sentences that make their essays rather chaotic

iv. Inappropriate use of connectives and meaning markers in their essays

v. Inability to write good introductions that contain clear thesis statements 


\section{vi. Lack of substantial content}

It is clear that the product approach to the teaching of essay writing makes the students vulnerable for committing avoidable errors.

On the textual structure, it was found that some of the students $(48.7 \%)$ had the structure that was required in an expository essay per the Genre Theory but 36 students representing $24 \%$ performed very poor in the structure. A tutor stated that "students of this college need to learn about the different structural elements of writing essays in order to become proficient writers either than that, they will always fall short of communicating better through their writings". Again, 82 (54.7\%) of the students knew how to link ideas in their essays. Some of the words used include: first, second, third, for example, for instance, in brief, in conclusion, as I have shown, as I have said, as a result, consequently, however, nevertheless, additionally, etc. However, some of the students $(25.3 \%)$ had challenges with the use of these discourse markers. It was evident from the essay that, irrespective of the fact that students had an awareness of these discourse markers, they had no idea how they are used in the written discourse.

With the parameter on topic expression, 75 (30\%) of the students had good grades. These were the students who were able to identify the structure the essay had to take, wrote good introduction and developed good paragraphs and also concluded their essays very well. A writer does this by using persuasion through a careful choice of vocabulary. The content of the information or discourse should be clear and specific. Again, 45 students representing $30 \%$ had poor marks and 30 of them had very poor marks as their performance was not good at all.

\section{Errors in writing essays (argumentative/expository)}

\begin{tabular}{ll}
\hline Error Type & Examples \\
\hline Lexical Errors & \\
\hline $\begin{array}{l}\text { Wrong words not based on the proper use of } \\
\text { English }\end{array}$ & $\begin{array}{l}\text { Turough (through), safetness (safeness), flip } \\
\text { over (turn over), adaje (adage), }\end{array}$ \\
\hline Word Order & \\
\hline English odd word order & Have we ever think about the need... \\
\hline
\end{tabular}

The errors are the parts or process which cannot be separated of the language learning especially English as a foreign language. The errors are signs that the students are really learning the foreign language.

According to the teachers, the students are supposed to have acquired some skills before coming down to the classroom.

"Sometimes you get to the classroom and its atmosphere looks as if they have no skill at all" (Interview with Teacher ' $B$ ') 
Furthermore, it emerged that all English Language Tutors in the College use the Explicit Instruction to teach the students during English writing lessons but due to their poor study habits and already poor foundation in the language, their performance is not as expected.

"I will say their study habits are mixed. So, the best option is to use Explicit Instruction to teach the students" (Interview with teacher ' $\mathrm{C}$ ')

There are many problems that we find with their writing. This statement confirms what is going on in the classroom. During the data collection and marking processes, it was found out that the majority of students make petty mistakes in their writings. It was found from the study that the students' errors hinge on grammar, spelling, punctuation and vocabulary. Again, the teachers were of the view that through Explicit Instructions, "students will have the opportunity to go through their lesson and then selfmonitor and direct their own learning and participation".

"Explicit Instruction is very important as it gives us, or it gives students the direct attention to understand their specific learning" (interview session with Teacher A).

For the essay types, the argumentative and the expository are the essay types which students find very difficult to write. Their problem with the challenge is based on the fact that most of them don't like reading. The respondents further proffered that in an essay writing classroom, students are expected to contribute in lessons and this will ensure that they are following the instructions that have been given to them.

\section{Summary of errors}

\begin{tabular}{lllllllll}
\hline & $\mathrm{N}$ & $\begin{array}{l}\text { Word } \\
\text { Tokens }\end{array}$ & $\begin{array}{l}\text { Total } \\
\text { errors }\end{array}$ & $\begin{array}{l}\text { Lexical } \\
\text { errors }\end{array}$ & $\begin{array}{l}\text { Word } \\
\text { order }\end{array}$ & $\begin{array}{l}\text { Missing } \\
\text { words }\end{array}$ & $\begin{array}{l}\text { Verb } \\
\text { use }\end{array}$ & $\begin{array}{l}\text { Verb } \\
\text { form }\end{array}$ \\
\hline Participants & 150 & 58954 & 2561 & 952 & 250 & 354 & 1200 & 135 \\
\hline
\end{tabular}

According to the findings and analysis directly above, the researcher found that the students made errors such as omission, addition, misinformation and mis-ordering in their essay writing. Based on the result, it was observed that the students made errors such as word order (250), verb use (1200), lexical errors (952) and verb forms (135). It means that most of the students made errors in their essay writing. 


\section{What activities and strategies do Tutors employ to help Students acquire writing skills and find success in their writing exercises?}

Activities and Strategies that are used to help students in their writing class

\begin{tabular}{|c|c|c|c|}
\hline No. & Items & Agree & Disagree \\
\hline 1. & I give direct/explicit instruction & 4 & \\
\hline 2. & Pre-writing activities are done to prepare students for writing & 2 & 2 \\
\hline 3. & $\begin{array}{l}\text { Elicit response from students during lessons using probing } \\
\text { question }\end{array}$ & 4 & \\
\hline 4. & Clear instructions are given to students before writing begins & 3 & 1 \\
\hline 5. & Engage students actively & 4 & \\
\hline 6. & Lesson is presented systematically & 4 & \\
\hline 7. & The use of a particular writing approach & 4 & \\
\hline 8. & I end lesson by reviewing and reflecting on lesson taught & 3 & 1 \\
\hline 9. & I give immediate corrective feedback & 4 & \\
\hline 10. & I build-up on what is being discussed on the board & 4 & \\
\hline 11. & I ask a lot of questions & 4 & \\
\hline 12. & Large class size is a hindrance to my effective teaching & 4 & \\
\hline
\end{tabular}

It can be deduced from the result that before any writing class begins, tutors prepare the students adequately. However, three (3) tutors were in disagreement with the assertion that pre-writing activities are done to prepare students for writing whilst 3 stated that tutors end lesson by review and reflecting on lesson taught. Teachers' personal beliefs about writing are the core from which decisions about the role of writing within the curriculum and the nature of writing instruction emanate. They emphasize the value of writing and underscore that it can be difficult but also exciting and fun.

Tutors have to provide students with the correct information to write on when they realize students do not have the information to use in their essays. A respondent stated that:

The students are supposed to have acquired some skills before coming down to the classroom. But sometimes you get to the classroom and the atmosphere looks as if they have no skill at all. And this, I know is worrisome because you expect that students have some skills in some petty or some little little things, but it so happens that they don't. And so it's quite worrisome. For instance, they have little knowledge when it comes to vocabulary items register to use for particular writing situations and so on and so forth. So, I think that is what I can say for now (Interview with Tutor ' $\mathrm{A}$ ' on $5^{\text {th }}$ March, 2021) 
According to the tutor respondents, after Explicit Instructions, students must coordinate several cognitively costly activities including retrieval of prior knowledge, planning and structuring content, formulating sentences, and monitoring output. They maintained that students need to maintain in mind their communicative goals and the needs of their audience. Writing competence requires not only automatization of transcriptions skills but also self-regulation in order to handle high-level cognitive processes of writing such as planning and revision, which are directly related to the production of high-quality texts.

\section{Activities and Strategies that help students in their writing in class}

\begin{tabular}{lll}
\hline Items & Agree & Disagree \\
\hline Follows instruction given by teacher & $45(75)$ & $15(25)$ \\
Contribute to lesson by answering questions & $46(76.7)$ & $14(23.3)$ \\
Write down discussions as they are made in class & $27(45)$ & $33(55)$ \\
Use feedback from teacher to improve on their writing & $40(66.7)$ & $20(33.3)$ \\
Use feedback from mates to improve on their writing & $8(13.3)$ & $52(86.7)$ \\
Join in the oral discussion that goes on in the lesson & $38(63.3)$ & $22(36.7)$ \\
Do not pay attention in class & $54(90)$ & $6(10)$ \\
Show signs that I am comfortable and follow lesson delivery in class & $48(80)$ & $12(20)$ \\
\hline
\end{tabular}

The results shows that all the students follow instructions from the tutor when it comes to lesson in class. From the data above, 54 making (90\%) of the students were not paying attention and seemed not to be part of the class. Few of the students were engaged in the lesson in class whilst majority simply sat through the lessons writing down information as the discussion was going on. One thing students took advantage of was the contributions their mates made during the discussion. And this was written on the board by the tutor to build up the points for the essay which students copied for future used.

Out of a total of 60 respondents who were observed during a lesson on writing, 35 students which is $55 \%$ did not write down anything as discussion were going on while others also did not use feedback from mates to improve on their writing. On the other hand, 46(76.7\%) agreed with the statement that they contribute to lesson by answering questions with $23.3 \%$ being in disagreement with the statement. Furthermore, it was realized that, activities such as feedback from teacher to improve on their writing, joining in the oral discussion that goes on in the lesson helps the student to improve upon her writing skills.

Corrective feedback is given to students when it was observed that students were making mistakes in their writing skills. A tutor had this to say:

With respect to the errors, I ensure that the highest percentage of errors in the verb category followed by the sentence structure category and then the word, 
noun ending, and article errors, respectively are corrected. I try as much as possible to help each student in my class because their development is important to me. But the problem of feedback, however, seems more serious in the case of the writing skill in crowded classes and very busy teachers make providing efficient and sufficient feedback a very hard job (Interview with Tutor C).

The objective of the language class and particularly the writing course is to help the students write well-organized expository and argumentative essays. However, the researcher emphasized the role of grammatical accuracy and the fact that a part of the students' job was to identify and correct their grammatical errors. The two essays were returned to the students for in-class revisions.

On the type of instructions that the tutors used during their teaching, the four (4) participants identified Explicit Instructions as the type of instruction that mostly informed their teaching.

The kind of essay that we teach them here requires that you give them Explicit Instruction. Because there are specific kinds of essays that we deal with, so normally I use Explicit Instruction because they will have to satisfy a particular kind of essay that they are supposed to write. I use the explicit writings (Interview Session with Tutor D).

Another tutor said:

For the instructions there are many types. But the best one or the one that I prefer is the Explicit or the Direct approach. I think the direct approach is a structured instruction, it is a systematic method of teaching here, the teacher goes step by step and the students are also involved in the teaching and I think that is the best one.

Tutors used Explicit Instructions in the classroom although it is engaging. According to them, it ensures that they do self-monitoring and directs their teachings.

\section{Discussion}

An analysis of the data revealed that that combining the cognitive strategy of text structure knowledge application with the metacognitive strategy of self-monitoring supports the development of academic writing in students. They need to learn, apply, and broaden metacognitive strategies in 
order to master academic demands in writing. Furthermore, the study was that students with high metacognition awareness often take advantage of the positive experience they have to try better and minimize negative experiences. Again, the role of the teacher is to utilize student metacognitive explicitly to design activities and tasks to help students become proficient in selfregulation. Students made mistakes in their writing. These included; verb errors, noun ending errors, article errors and wrong words. It was realized that their ideas were quite logical, but they had a lot of grammar errors. Students indicated that they did not know how, but sometimes the errors came due to the pressure in the classroom. The findings from this research study showed that teachers read the students' writing, identified common errors, and worked with the students towards improving their writings. Activities based on the students' own thoughts helped them to be creative in productive skills

With regards to Explicit Instruction in the classroom, the study revealed that tutors comprehensively used instructions in the language class to enhance students writing skills. Tutors have a central role to play in setting up facilitative environments. Tutors were of the view the instructional time of one hour was not enough to teach a large class like the language class. When compared to previous studies' findings, it was discovered that these findings are more specific, while previous studies' findings were more general (Bustomi, 2009). Additionally, Clark (2013) is of the view that if tutors aim to impart knowledge in the classroom, then there is the need to teach students how to write better. Through providing students with the natural feedback by which they discover the laws of writing, students' sentence-level language skills and vocabularies can improve. Teaching writing and reading helps students improve sub-writing skills such as spelling, handwriting, grammar, and punctuation. For instance, Robb et al. (1986) determined the complexity of their students' writing by counting the number of additional clauses written in the revised essays, while Sheppard (1992) has measured the essay complexity by reference to the number of subordinations. Goeke's (2008) assertion that teachers should help students stay actively involved in the lesson in order to have the greatest impact on their learning is in the right direction. Tutors must let students know that they value good writing. Tutors must stress the importance of clear, thoughtful writing. Tutor who tells students that good writing will be rewarded and poor writing will be penalized receive better essays than tutors who do not make such demands. In the syllabus, on the first day, and throughout the term, students must be reminded that they must make their best effort in expressing themselves on paper. One way in which the tutors can help their students find errors in their own writing is by using self-editing checklist, bearing in mind that no students can correct their own grammatical errors. Tutors need to respond positively to the ideas that are 
expressed and the spellings that have been attempted before discussing how spelling could be improved.

\section{Conclusion}

The study's primary objective was pedagogical, which means that its results are largely meant to support tutors of the English language and writing abilities of students. The necessity to communicate effectively through written expression will only increase as technology becomes more advanced. Thus, implementing an intervention that could increase students' attitudes toward writing, text production, inclusion of important details, and use of writing conventions, has the potential to provide a brighter future for our youth. Tutors must be willing to commit to providing quality writing instruction and they must assist the students' multiple opportunities during the week to write as well as provide them with constructive feedback to ensure that they see their writing errors and are able to make corrections using the strategies they learnt during writing instruction. Explicit instruction especially in the context of authentic writing activities, is advised to ensure correct and fluent application of basic writing skills during text production. Activities that support the development of content for writing (e.g., pre-writing activities that may help learners construct background knowledge about a topic, brainstorming ideas based on existing knowledge, completing graphic organizers that signpost with keywords a flexible network of ideas) help students produce higher quality essays.

\section{Recommendations and Implications}

Based on the findings from the study tutors must have knowledge of a variety of evidence-based instructional practices that improve many different skills in student's writing. One reason Explicit Instruction could be effective in teaching writing is because it builds on conceptual and procedural knowledge in direct ways. Again, the researcher recommends that tutors of other subjects should try to speak or use the Standard English in the classroom and outside the classroom since their linguistic competence is seen as the trump card for proficiency in the use of the language. They should also be aware that they are using English language as a medium of instructions to communicate the lessons in their subject areas therefore; it is their potent duty to use the Standard English within and outside the classroom. Explicit Instruction especially in the context of authentic writing activities, is advised to ensure correct and fluent application of basic writing skills during text production. Technology continues to advance at a rapid pace, and the technological tools available to support writers expand every few months. Additionally, students who struggle with writing are likely to benefit from the 
thoughtful use of technology to eliminate or diminish the barriers they encounter in successful text production.

\section{References:}

1. Adebiyi, E .F. (2021). Effects of explicit and generative instructional strategies on students' achievement in reading comprehension in Ikere Local Government Area of Ekiti State. An unpublished M.Ed Project submitted to the Department of Teacher Education, University of Ibadan, Ibadan.

2. Akinoso, S.O. (2012). Effects of concrete-representational-abstract and explicit instructional strategies on senior secondary school students' in and attitude to mathematicse. A PhD Post-Field Report presented at the Joint Staff/Higher Degree Students Seminar, Department of Teacher education, University of Ibadan, Ibadan.

3. Alfaki, M. (2015). University student's English writing problems: Diagnosis and remedy. International Journal of English Language Teaching, 3, 40-52.

4. Amer, M. (2013). The Effect of Explicit Instruction in Expository Text Structure Of The Writing Performance Of Arab EFL University Students. Arab World English Journal, 4(1), 244 - 238.

5. Archer, A. L., \& Hughes, C. A. (2011). From Explicit Instruction: Effective and efficient teaching. New York: The Guilford Press.

6. Bereiter, C., \& Scardamalia, M. (1987). The psychology of written composition. New York: Lawrence Erlbaum Associates, Inc.

7. Berliner, D. C. (1980). Using research on teaching for the improvement of classroom practice. Theory into Practice, 19(4), 302308.

8. Bitchener, J. \& Barsturkmen, H. (2006). Perceptions of the difficulties of postgraduate L2 thesis students writing the discussion section. Journal of English for Academic Purposes, 5, 4-18.

9. Bomer, R. (1998). Transactional heat and light: More explicit literacy learning. Language Arts, 76(1), 11-18.

10. Bransford, J. D., Brown, A. L., \& Cocking, R.R. (2000). How people learn: Brain, mind, experience and school (expanded ed.). Washington, DC: National Academy Press.

11. Briggs, C.L. (2007). Anthropology, interviewing, and communicability in contemporary Society. Current Anthropology, 48(4), 551-580.

12. Brooks, A., Vaughan, K., \& Berninger, V. (1999). Tutorial interventions for writing disabilities: Comparison of transcription and text generation processes. Learning Disability Quarterly, 22(3), 183190. 
13. Brophy, J. E., \& Evertson, C. M. (1976). Learning from teaching: A developmental perspective. Boston, MA: Allyn and Bacon

14. Brown, A. (1987). Metacognition, executive control, self-regulation, and other more mysterious mechanisms. In F. E. Weinert \& R. H. Kluwe, (Eds.) Metacognition, motivation, and understanding (pp. 65116). Hillsdale, NJ: Lawrence Erlbaum.

15. Bruning, R. \& Horn, C. (2000). Developing Motivation to Write. Educational Psychologist, 35, 25-37

16. Bui, K. V. T. (2002). First-generation college students at a four-year university: Background characteristics, reasons for pursuing higher education, and first-year experiences. College Student Journal, 36(1), 3-11.

17. Bustomi, Ahmad. (2009). Error analysis on students' descriptive writing: A case study on students of Harapan Jaya Senior High School at Cipondoh, Tangerang. Jakarta: State Islamic University Syarif Hidayatullah.

18. Butler, D. L., \& Winne, P. H. (1995). Feedback and self-regulated learning: A theoretical synthesis. Review of Educational Research, 65(3), 245-281.

19. Byrne, D. (1993). Teaching Writing Skills. London: Longman Press

20. Christenson, S. L., Ysseldyke, J. E., \& Thurlow, M. L. (1989). Critical instructional factors for students with mild handicaps: An integrative review. Remedial and Special Education, 10(5), 21-31.

21. Clark, C. M. (2013). The effects of explicit writing instruction. Graduate Research papers, 35. Retrieved from https://scholarsworks.uni.edu/grp/35

22. Corbin, J. \& Strauss, A. (2008). Basics of qualitative research: Techniques and procedures for developing grounded theory ( $\left.3^{\text {rd }} \mathrm{ed}.\right)$. London: Sage.

23. Crown, S.L. (2009). Using Explicit Instructional Strategies to teach narrative writing. Teachers as learners: Improving outcomes for Maori and Pasifika students through inquiry. Retrieved from http://nzcurriculum.tki.org.nz/Inquiry

24. De La Paz, S. (2009). Rubrics: Heuristics for Developing Writing Strategies. Assessment for Effective Intervention, 34(3), 134-146.

25. Dewyer, C. P., Hogan, M. J., \& Stewart, I. (2014). An integrated critical thinking framework for the $21^{\text {st }}$ century. Thinking Skills and Creativity, 12, 43-52.

26. Dinsmore, D. L., Alexander, P. A., \& Loughlin, S. M. (2008). Focusing the conceptual lens on metacognition, self-regulation, and self-regulated learning. Educational Psychology Review, 20, 391-409. 
27. Dockrell, J. E., Marshall, R. C., \& Wyse, D. (2015). Reading and writing. Teachers' Reported Practices for teaching writing in England. Reading and Writing., 2016(29), 409-434.

28. Duke, N.K. (2000). 3.6 minutes per day: The scarcity of informational texts in first grade. Reading Research Quarterly, 35, 202-224.

29. Duke, N.K. (2001). Building comprehension through explicit teaching of comprehension strategies. A paper presented at the Second $\left(2^{\text {nd }}\right)$ Annual MRA/CIERA Conference held on September 22 ${ }^{\text {nd }}, 2001$. Michigan State University.

30. Feng, S., \& Powers, K. (2005). The short- and long-term effect of explicit grammar instruction on fifth graders' writing. Reading Improvement, 42(2), 67-73.

31. Fink, L. (2013). Creating significant learning experiences: An integrated approach to designing college courses. San Francisco, CA: Jossey-Bass.

32. Flavell, J. H. (1979) Metacognition and cognitive monitoring: A new area of cognitive-developmental inquiry. American Psychology, 34. 906-911.

33. Garofalo, Joe \& Lester, Frank. (1985). Metacognition, Cognitive Monitoring, and Mathematical Performance. Journal for Research in Mathematics Education, 16(3), 163-176.

34. Gettinger, M. \& Seibert, J.K. (2002). Best practices in increasing academic learning time. In A. Thomas \& J. Grimes (Eds.), Best practices in school psychology, (pp. 773-787). Bethesda, MD: National Association of School Psychologists.

35. Glaser, B., \& Strauss, A. (1967). The discovery of grounded theory strategies for qualitative research. Mill Valley, CA Sociology Press.

36. Goeke, J. L. (2008). Explicit Instruction: A Framework for Meaningful Direct Teaching. Boston, MA: Allyn \& Bacon.

37. Graham, S., Harris, K. R., \& Larsen, L. (2001). Prevention and intervention of writing difficulties for students with learning disabilities. Learning Disabilities Research \& Practice, 16, 74-84.

38. Graham, S., \& Harris, K. R. (2000). The role of self-regulation and transcription skills in writing and writing development. Educational Psychologist, 35(1), 3-12.

39. Greiner, A., \& Simmons, C. (2012). The write tools. LLC. Continental: Co64

40. Hall, T. (2002). Explicit instruction. Wakefield, MA: National Center on Accessing the General Curriculum. Retrieved from:

41. http://aim.cast.org/learn/historyarchive/backgroundpapers/explicit_in struction 
42. Halpern, D. F. (1998). Teaching critical thinking for transfer across domains: Dispositions, skills, structure training, and metacognitive monitoring. American Psychologist, 53(4), 449-55.

43. Hartman, H. J. (2001). Developing students' metacognitive knowledge and skills. In: Hartman, H. J. (Eds.), Metacognition in learning and instruction (pp. 33-68). Springer, Dordrecht.

44. Hartshorn, K. J., Evans, N. W., Merrill, P. F., Sudweeks, R. R., StrongKrause, D., \& Anderson, N. J. (2010). Effects of dynamic corrective feedback on ESL writing accuracy. TESOL Quarterly, 44, 84-108.

45. Hattie, J., Gurung, R. A. R., \& Landrum, R. E. (2015). The applicability of visible learning to

46. higher education. Scholarship of Teaching and Learning in Psychology, 1(1), 79-91.

47. Hinkel, E. (2002). Second language writers' texts: linguistic and rhetorical features. Mahwah, NJ: Lawrence Erlbaum.

48. Hinkel, E. (2004). Teaching academic ESL writing: practical techniques in vocabulary and grammar. Mahwah, NJ: Lawrence Erlbaum.

49. Hmelo-Silver, C. E. (2004). Problem-based learning: What and how do students learn? Educational Psychology Review, 16, 235-266.

50. Hughes, C. A., Morris, J. R., Therrien, W.J. \& Benson, S. K. (2017). Explicit Instruction: Historical and contemporary contexts. Learning Disabilities, Research and Practice, 32(4), 140-148.

51. Joseph, L. M., Alber-Morgan, S., \& Neef, N. (2016). Applying behavior analytic procedures to effectively teach literacy skills in the classroom. Psychology in the Schools, 53(1), 73-88.

52. Justice, E. M., \& Dornan, T. M. (2001). Metacognitive differences between traditional-age and nontraditional-age college students. Adult Education Quarterly, 51(3), 236-49.

53. Koster, M., Tribushinina, E., De Jong, P. F., \& van den Bergh, B. (2015). Teaching children to write: A meta-analysis of writing intervention research. Journal of Writing Research, 7(2), 300-324.

54. Langan, J. (2008). Sentence skills: A workbook for writers, form $B$ ( $8^{\text {th }}$ Ed.). New York, NY: McGraw-Hill

55. Leki, I., Cumming, A., \& Silva, T. (2008). A synthesis of research on second language writing in English. New York: Routledge.

56. Narciss, S., Proske, A., \& Koerndle. H. (2007). Promoting selfregulated learning in web-based learning environments. Computers in Human Behavior, 23(3), 1126-1144.

57. National Research Council (2001). Knowing what students know: The science and design of educational assessment. In J. Pellegrino, R. 
Glaser, \& N. Chudowsky (Eds.), Committee on the Foundations of Assessment. Washington, DC: National Academy Press.

58. Newcomer, P. L. \& Barenbaum, E. M. (1991). The written composing ability of children with learning disabilities: A review of the literature from 1980-1990. Journal of Learning Disabilities, 24, 578-593.

59. Newell, G., Beach, R., Smith, J. \& Van Der Heide, J., (2011). Teaching and learning argumentative reading writing: A review of research. Reading Research Quarterly, 46(3), 273-304.

60. Olagbaju, O.O. (2019). Effects of explicit instructional strategy and cognitive styles on achievement of senior secondary students in summary writing in Ibadan, Nigeria. Global Scientific Journals, 7(6), 58-79

61. Ormrod, J. E. (2011). Human Learning ( $6^{\text {th }}$ ed.). Upper Saddle River, NJ: Prentice Hall.

62. Oshima, A. \& Houge, A. (1991). Writing academic English: A writing and sentence structure handbook. Cambridge: Addison-Wesley Publishing Company

63. Palincsar, A. S., \& Klenk, L. (1992). Fostering literacy learning in supportive contexts. Journal of Learning Disabilities, 25(4), 211-225, 229.

64. Patton M.Q. (2002). Qualitative research and evaluation methods. Thousand Oaks, CA: Sage Publications

65. Pintrich, P. R. (2004). A conceptual framework for assessing motivation and self-regulated learning in college students. Educational Psychology Review, 16, 385-407.

66. Pressley, M., Rankin, J., \& Yokoi, L. (1996). A survey of instructional practices of primary teachers nominated as effective in promoting literacy. Elementary School Journal, 96, 363-384.

67. Price, D.P. (1998). Explicit instruction at the point of use. Language Arts, 76, 1, 19-26.

68. Raimes, A. (1983). Techniques in teaching writing. Oxford: OUP.

69. Robb, T., Ross, S., \& Shortreed, I. (1986). Salience of feedback on error and its effect on EFL writing quality. TESOL Quarterly, 20, 8393

70. Rozencwajg, P. (2003). Metacognitive factors in scientific problemsolving strategies. European Journal of Psychology of Education, 18, 281-294.

71. Salahu-Din, D., Persky, H., \& Miller, J. (2008). The nation's report Card TM: Writing 2007.

72. National assessment of educational progress at grades 8 and 12. National, state, and trial urban district results. NCES 2008-468. National Center for Education Statistics. 
73. Schraw, G., Crippen, K., \& Hartley, J. (2006). Promoting selfregulation in science education: Metacognition as part of a broader perspective on learning. Research in Science Education, 36(1), 111139.

74. Schunk, D. H., \& Zimmerman, B. J. (2007). Influencing children's selfefficacy and self-regulation of reading and writing through modeling. Reading \& Writing Quarterly, 23(1), 7-25.

75. Serafini, F. (2004). Lessons in comprehension: Explicit Instruction in the reading workshop. Portsmouth, NH: Heinemann.

76. Setyowati, L., \& El - Sulukiyyah, A. A. (2019). Explicit Planning for Paragraph Writing Class. Researchgate Journal Bahasa Lingua Scientia, 9(2), 241-260

77. Sheppard, K. (1992). Two feedback types: Do they make a difference? RELC Journal, 23, 103-110.

78. Silva, T. (1993). Toward an understanding of the distinct nature of L2 writing: the ESL Research and its implications. TESOL Quarterly,27, 657-675.

79. Starkey, L. (2004). How to write great essays. New York: Learning Express

80. Sternberg, R. J. (1998). Metacognition, abilities, and developing expertise: What makes an expert student? Instructional Science, 26, 127-140.

81. Sternberg, R. J. (2003). Creative thinking in the classroom. Scandinavian Journal of Educational Research, 47(3), 325-338.

82. Tarnopolsky, O. (2000). Writing English as a second or foreign language: A report from Ukraine. Journal of Second Language Writing, 9(3), 209-226.

83. Tsegaye, M. (2006). The Writing Problems of Preparatory Students with Reference to Injibara Preparatory School. (Unpublished MA Thesis). Addis Ababa: Addis Ababa University.

84. Viel-Ruma, K. A. (2008). The effects of direct instruction in writing on english speakers and english language learners with disabilities. Available at: Pro Quest Dissertations and Theses Global.

85. Wolters, C., \& Pintrich, A. (1998). Contextual differences in student motivation and selfregulated learning in mathematics, English, and social studies classrooms. Instructional Science, 26(1), 27- 47.

86. Wong, B. Y. L., Butler, D. L., Ficzere, S. A., \& Kuperis, S. (1997). Teaching adolescents with learning disabilities and low achievers to plan, write, and revise compare-and-contrast essays. Learning Disabilities Research \& Practice, 12(1), 2-15. 
87. Zhu, W. (2001). Performing argumentative writing in English: Difficulties/ processes/ and strategies. TESL Canada Journal, 19(1), 34-50.

88. Zull, J. E. (2011). From brain to mind. Sterling, VA: Stylus Publishing, LLC. 